\title{
Influence of Root Zone Calcium on Subapical Necrosis in Potato Shoot Cultures: Localization of Injury at the Tissue and Cellular Levels
}

\author{
James S. Busse \\ Department of Horticulture, University of Wisconsin, Madison, WI 53706 and United States \\ Department of Agriculture, Vegetable Crops Research Unit, Madison, WI 53706 \\ Senay Ozgen \\ Department of Horticulture, University of Wisconsin, Madison, WI 53706 and Department \\ of Horticulture, University of Gaziosmanpasa, Tokat 60240, Turkey \\ Jiwan P. Palta ${ }^{1}$ \\ Department of Horticulture, University of Wisconsin, Madison, WI 53706
}

\begin{abstract}
ADDITIONAL INDEX WORDS. micropropagation, shoot tip, apical dominance, axillary shoot growth, tip necrosis, Solanum tuberosum, calcium deficiency

Abstract. Shoot tip necrosis has been attributed to calcium deficiency in in vitro cultures, resulting in death of the stem tip, the loss of apical dominance, and axillary branch development. Using an in vitro shoot culture system with Solanum tuberosum L. cv. Dark Red Norland, we studied the development of injury symptoms at the microscopic and tissue levels at a range of media calcium concentrations varying from 6.8 to $3000 \mu \mathrm{M}$. Light and electron microscopic studies revealed that the primary injury due to calcium deficiency was the death and collapse of expanding pith cells below the shoot apex. The structure and organization of the shoot apical meristem was the same when plants were cultured on sufficient or suboptimal media calcium concentrations. However, the apical meristem senesced following subapical shoot tissue collapse. Death of the shoot apical meristem was a secondary effect of calcium deficiency, resulting in loss of apical dominance. Studies with ${ }^{45} \mathrm{Ca}$ indicated that calcium was distributed in a gradient along the shoot, with highest concentration at the base and the lowest at the apex. Shoot tip necrosis developed after 20 days of culture on the suboptimal calcium concentration medium. The development of these symptoms and axillary shoot growth was associated with the lack of calcium accumulation in the shoots. Our results provide evidence that a primary injury of calcium deficiency is localized in the expanding pith cells below the shoot apical meristem and this injury results in the collapse of subapical cells. Death of the shoot apical meristem is a secondary injury resulting from calcium deficiency.
\end{abstract}

Calcium is an essential macronutrient for plant growth derived from the growing medium. Calcium ions are essential for cell wall strengthening and cell-cell adhesion (Marry et al., 2006; Marschner, 1995). Pectic polysaccharide rhamnogalacturonan portions of the middle lamella are cross linked by calcium ions (Matoh and Kobayashi, 1998) Calcium bound to the outer surface of the plasma membrane maintains membrane stability and cell integrity (Hanson, 1984; Hirschi, 2004; Palta, 1996). For example, cell death following freezing injury has been attributed to ion leakage caused by calcium loss from the plasma membrane (Arora and Palta, 1986). In addition, calcium is known to have a prominent role as a second messenger coupling stimuli such as environmental stress, and light and plant hormones to a response (Bush, 1995; Ng and McAinsh, 2003; Sanders et al., 1999).

Calcium is largely immobile in the phloem, and is distributed with water in the transpiration stream (White and Broadley, 2003). Thus, calcium deficiency symptoms are

Received for publication 5 Nov. 2007. Accepted for publication 16 Apr. 2008. We sincerely thank Laura VanderPloeg, senior media specialist in the University of Wisconsin-Madison Biochemistry Department, for assisting with figure preparation, and Claudia Lipke, senior artist in the University of Wisconsin-Madison Botany Department, for photographing the material in Figure 1.

${ }^{1}$ Corresponding author. E-mail: jppalta@wisc.edu. observed in tissues with a low transpiration rate, including young expanding leaves, enclosed shoot tissues, fruits, underground tubers, and in portions of the plant principally fed by phloem rather than xylem (White and Broadley, 2003). Shoot tip necrosis, a physiological disorder observed during $S$. tuberosum in vitro culture has been attributed to calcium deficiency (McCown and Sellmer, 1987; Sha et al., 1985). This condition is typified by the browning and death of the shoot tip, the loss of apical dominance, and axillary branch development in an in vitro shoot culture system (McCown and Sellmer, 1987; Sha et al., 1985). Transpiration is limited during in vitro culture by high humidity brought about with nearly closed culture vessels. Therefore, the uptake and transport of calcium ions, which is dependent on transpiration, may be limited during in vitro culture (Williams, 1993). In addition to in vitro shoot culture of S. tuberosum, shoot tip necrosis has been observed in shoot cultures of Pistacia vera L. in relation to calcium deficiency (Abousalim and Mantell, 1994). Results from these studies suggest that shoot tip necrosis, a symptom of calcium deficiency, can be precisely controlled and studied by regulating root zone calcium concentration using in vitro culture. Despite this fact, shoot culture systems have not been exploited to study growth and development regulation by nutrients in the root zone.

Our objective was to study shoot tip necrosis symptoms at the cellular level. We precisely defined the medium calcium 
concentration for the development of shoot tip necrosis symptoms. Sha et al. (1985) used media containing $0.3,3.0$, and 30.0 $\mu \mathrm{M}$ calcium and culture vessels containing multiple plants in each vessel. While the authors were able to show a relationship between shoot tip necrosis and the medium calcium concentration, they were not able to do precise experiments at the individual plant level owing to the interplant competition in the culture vessels. The exact medium calcium concentration for a given shoot could not be defined. The in vitro system we used allowed us to describe the structural basis of the symptoms at the tissue and cellular level. We further show that primary symptoms develop just below the shoot apical meristem where internode elongation occurs - the subapical region. We also demonstrate that this primary injury results in a collapse of tissue in the subapical region, causing the death of the shoot apical meristem and loss of apical dominance. Using ${ }^{45} \mathrm{Ca}$ as a tracer, we tracked the distribution of calcium in the shoot under sufficient and deficient media calcium levels. Our results provide evidence for the involvement of calcium in subapical necrosis and we demonstrate that a shoot culture system can be used to further study the mechanism by which a lack of calcium causes loss of apical dominance.

\section{Materials and Methods}

Culture Procedure. Micropropagated 'Dark Red Norland' potato plants were grown on Murashige and Skoog (MS) medium (Murashige and Skoog, 1962) using single-node cuttings taken from the second and third nodes below the shoot tip. Culture medium supplemented with 6.8, 34.0, 170.0, 850.2, or $3000 \mu \mathrm{m}$ calcium using calcium chloride as a source. Culture media contained 3\% sucrose, $0.56 \mathrm{~mm}$ myo-inositol, and $0.8 \%$ agar (Sigma-Aldrich, St. Louis). The $\mathrm{pH}$ was adjusted to $5.6 \pm$ 0.02 . Media was autoclaved at $132{ }^{\circ} \mathrm{C}$ for $10 \mathrm{~min}$ before use. Plants were cultured in $20 \times 150-\mathrm{mm}$ glass tubes capped with a KIM-KAP $^{\text {TM }}$ (Kimble/Konte, Dusseldorf, Germany) containing $9 \mathrm{~mL}$ of media. Culture tubes were placed under continuous light at $60 \mu \mathrm{mol} \cdot \mathrm{m}^{-2} \cdot \mathrm{s}^{-1}$ photosynthetic photon flux density from cool white fluorescent lamps measured at the top of the culture tubes. The temperature was maintained at $22 \pm 2{ }^{\circ} \mathrm{C}$. Observations were made 14 to $28 \mathrm{~d}$ after culture.

SCANNing ELECTRON Microscopy. Shoot tips from each medium calcium concentration and age were fixed for $4 \mathrm{~h}$ in $5 \%(\mathrm{w} / \mathrm{v})$ glutaraldehyde in $0.05 \mathrm{~m}$ sodium cacodylate buffer, $\mathrm{pH} 7.0$, with a change of fresh fixative after the first $2 \mathrm{~h}$. Tissue was rinsed with buffer, dehydrated through a graded ethanol series, and critical point dried. An Auto Conductovac IV (SEEVAC, Pittsburgh), coater applied $3500 \mathrm{~nm}$ of gold to the sample surface. The samples were viewed with a scanning electron microscope (model S-570; Hitachi, San Jose, CA) at 10 $\mathrm{kV}$ and photographed with an image capture system (Gatan, Warrendale, PA). Two shoot tips from each age and each medium calcium concentration were examined.

Light MICROSCOPY. Two shoot tips from each medium calcium concentration and age (14 and $21 \mathrm{~d}$ ) were fixed for $4 \mathrm{~h}$ in $5 \%(\mathrm{w} / \mathrm{v})$ glutaraldehyde in $0.05 \mathrm{M}$ sodium cacodylate buffer, pH 7.0, with a change of fresh fixative after the first $2 \mathrm{~h}$. Tissue was rinsed with buffer and postfixed with $2 \%(\mathrm{w} / \mathrm{v})$ osmium tetroxide in $0.05 \mathrm{M}$ sodium cacodylate, followed with several rinses with buffer. Samples were then dehydrated through a graded acetone series. All material was embedded in Spurr's resin and polymerized at $70{ }^{\circ} \mathrm{C}$ (Spurr, 1969). Two- micrometer-thick sections were cut with a Sorvall Porter-Blum MT-2 ultramicrotome (DuPont Co., Newtown, CT) and attached to glass slides with heat. Sections were stained with toluidine blue O, viewed with a light microscope (Ultraphot II; Carl Zeiss Meditec, Thornwood, NY), and photographed with TMAX 100 (Eastman Kodak, Rochester, NY).

Clearing intact SHOOT TIPS TO VISUALIZE PROGRession OF SHOOT TIP NECROSIS. Primary shoot tips from cuttings cultured on medium supplemented with $6.8,34.0,850.2$, or $3000 \mu \mathrm{M}$ calcium for 16 and $25 \mathrm{~d}$ were cleared in $75 \%(\mathrm{v} / \mathrm{v})$ lactic acid for $24 \mathrm{~h}$ before staining with pararosaniline hydrochloride (Boke, 1970). Following dehydration through an ethanol series, tissue was mounted in methyl salicylate on glass slides. The number of shoot tip clearings examined was $10(6.8 \mu \mathrm{M} \mathrm{Ca}$ medium, 16 d), 16 (6.8 $\mu \mathrm{M}$ Ca medium, $25 \mathrm{~d}), 8$ (34.0 $\mu \mathrm{M}$ Ca medium, $16 \mathrm{~d})$, 26 (34.0 $\mu \mathrm{M}$ Ca medium, $25 \mathrm{~d}), 8$ (850.2 $\mu \mathrm{M}$ Ca medium, $16 \mathrm{~d}), 8$ (850.2 $\mu \mathrm{M}$ Ca medium, $25 \mathrm{~d}), 8(3000 \mu \mathrm{M} \mathrm{Ca}$ medium, $16 \mathrm{~d})$, and 8 (3000 $\mu$ м Ca medium, 25 d).

DeVElopmental CHANGES IN SHOOTS DURING THE ONSET OF SHOOT TIP NECROSIS. The influence of media concentration on the onset of shoot tip necrosis was studied developmentally by culturing plants on sufficient $(1360 \mu \mathrm{M})$ and insufficient $(68 \mu \mathrm{M})$ calcium media concentrations. Plants were removed after 14, 21,28 , and $35 \mathrm{~d}$ of culture and were examined for the short tip viability and the development of axillary shoots. At the same time, shoots were removed by excising at the level of agar media and data were collected on shoot length, shoot fresh weight, and number of nodes per shoot. All of these observations were made on 20 separate plants on the sufficient and insufficient media calcium concentrations. Two shoots were combined and processed for quantifying calcium concentrations. Thus, for each treatment there were 10 calcium measurements. Since these were destructive samplings, at each time interval $(14,21,28$, and $35 \mathrm{~d}$ after culture), data were collected on separate plants.

Tissue Calcium analysis. A standard procedure as described by Kratzke and Palta (1986) was used for the extraction and quantification of tissue calcium. For this purpose, tissue samples were dried at $60{ }^{\circ} \mathrm{C}$, weighed, ashed $\left(500{ }^{\circ} \mathrm{C}, 6 \mathrm{~h}\right)$ and extracted in $2 \mathrm{M} \mathrm{HCl}$. This extract was diluted with lanthanum chloride $\left(\mathrm{LaCl}_{3} \cdot 7 \mathrm{H}_{2} \mathrm{O}\right)$ solution to obtain a final concentration of $0.2 \mathrm{M} \mathrm{HCl}$ and $2000 \mu \mathrm{g} \cdot \mathrm{mL}^{-1} \mathrm{LaCl}_{3}$. Calcium concentration was determined by atomic absorption spectroscopy using a SpectrAA-55B (Varian Instruments, Walnut Creek, CA). Two shoots were combined to make a sample for quantification of $\mathrm{Ca}$ by atomic absorption spectroscopy.

${ }^{45}$ Ca uptake AND Distribution. For experiments using radioactive calcium, ${ }^{45} \mathrm{CaCl}_{2}$ (Perkin Elmer Life Sciences, Boston) was added such that each culture tube had 15.91 $\mathrm{MBq}{ }^{45} \mathrm{Ca}$. All tissues were dried before ashing at $550{ }^{\circ} \mathrm{C}$. Liquid scintillation cocktail (ScintSafe 30\%; Fisher Scientific, Fair Lawn, NJ), was added before counting in the 0 to $252 \mathrm{keV}$ range for $10 \mathrm{~min}$ with three cycle repeats in an LS 1801 (Beckman Instruments, Fullerton, CA) liquid scintillation counter. Data from the scintillation counter was converted to becquerels. Autoradiographs were made using Kodak BIOMAX film and processed using the manufacturer's recommendations. In addition, shoots were cut into three equal segments to analyze the radioactivity present in top, middle, and bottom parts of the shoot.

STATISTICAL ANALYSIS. Data were analyzed using a model for a completely randomized design in PROC GLM procedure of 
SAS (version 8.2; SAS Institute, Cary, NC). Means were separated using the LSD test at $\alpha=0.05$.

\section{Results}

SyMPTOMS OF SHOOT TIP NECROSIS AND LOSS OF APICAL DOMINANCE. In vitro cultures of $S$. tuberosum 'Dark Red Norland' grew as a single unbranched shoot through the entire culture period on medium with sufficient calcium (Fig. 1A). Plants had elongated internodes and retained apical dominance after 29 d (Fig. 1A). Plants cultured on medium with a suboptimal calcium concentration had an altered morphology (Fig. 1B). Plants were shorter and had smaller leaves (Fig. 1B) compared with plants cultured on medium with sufficient calcium (Fig. 1A). Culture medium with a suboptimal calcium concentration resulted in necrosis just below the shoot tip (Fig. 1, D-F) and subsequent loss of apical dominance and prolific axillary branch development (Fig. 1B). Plants cultured on medium with sufficient calcium had shoot tips with no visible symptoms (Fig. 1C). Leaf and internode expansion occurred in a coordinated fashion below the shoot apex, resulting in an unbranched shoot (Fig. 1, A and C).

The first visible symptom of shoot tip necrosis was reduced leaf expansion near the shoot apex (Fig. 1D). Next, the stem became darkened 1 to $3 \mathrm{~mm}$ below the shoot tip (see arrow in Fig. 1E). The darkened stem tissue collapsed as symptoms progressed, resulting in a constriction below the shoot tip (see arrow in Fig. 1F). As necrosis in the subapical region of the stem compromised the shoot tip, axillary branch development began (Fig. 1, D-F). In some cases, the shoot tips of axillary branches underwent necrosis, resulting in secondary axillary branch development (Fig. 1B).

LocalizATION OF INJURY SYMPTOMS. Scanning electron microscopy was used to examine the shoot tip and shoot apical meristem of plants cultured on sufficient and suboptimal calcium concentration media (Fig. 2, A-D). Stem tissue collapse was not observed in cultures grown on $850 \mu \mathrm{M} \mathrm{Ca}$ medium (Fig. 2A). When plants were cultured on a suboptimal calcium concentration medium, $6.8 \mu \mathrm{M}$, stem tissue collapse occurred immediately below the shoot apical meristem (see arrows in Fig. 2B). With the subapical stem tissue collapse axillary shoot development was noted (see ab in Fig. 2B).

The shoot apical meristem showed no differences when shoots were cultured on sufficient (Fig. 2C) or suboptimal (Fig. 2D) calcium concentration media. The shoot apical meristem dome was clearly visible and leaf primordia associated with the apical meristem appeared similar regardless of medium calcium concentration (see P in Fig. 2, C and D).

Internal stem tissue health and organization was studied using sectioned and cleared material to further determine the cellular location of the symptoms in shoots cultured on suboptimal root zone calcium concentrations (Figs. 3 and 4). Longitudinal sections through the shoot tip revealed that the shoot apical meristem of plants cultured on sufficient or suboptimal root zone calcium concentrations had the same tunica/corpus organization (Fig. 3, A and B). The promeristem cells had similar size and were densely cytoplasmic, irrespective of the root zone calcium concentration (Fig. 3, A and B). Dermal, ground, and vascular tissue cells were vacuolated and revealed the expansion they had undergone after meristematic activity ceased in the region of stem elongation when shoots had been cultured with sufficient root zone calcium levels
(Fig. 3A). In contrast, cells from all three tissue systems were not expanded in shoots cultured on medium with a suboptimal root zone calcium concentration (Fig. 3B). These cells appeared senesced and collapsed (Fig. 3B). Senescence first occurred in the ground tissue before death of the dermal and vascular tissues in sectioned material. This indicated that injury began with the collapse of the pith cells.

Tissue clearings were used to further study development of shoot tip necrosis symptoms (Fig. 4). Again, no evidence of senescence was seen near the shoot tip of plants cultured on medium with sufficient calcium (Fig. 4A). Expanding ground tissue cells in the pith were observed to be the first cells to undergo senescence in shoots cultured on suboptimal concentrations of media calcium (Fig. 4B). Axillary shoot development was observed nearly at the same time as the earliest indications of shoot tip necrosis (Fig. 4B). As shoot tip necrosis continued, all tissue senesced and collapsed in the upper portion of the stem, resulting in shoot tip death (Fig. 4C). As the tissue advanced in age, shoot tip necrosis was also observed in axillary shoots (Fig. 4C).

INFLUENCE OF ROOT ZONE MEDIUM CALCIUM CONCENTRATION ON SHOOT GROWTH, SHOOT TIP NECROSIS, AND SHOOT CALCIUM ACCUMUlation. Experiments were conducted to investigate growth parameters and whole shoot calcium content on media with varied calcium concentrations (Tables 1 and 2). Mean shoot fresh weight increased about $30 \%$ as media calcium concentration increased from 68.0 to $272 \mu \mathrm{M}$; however, there was no increase in fresh weight at calcium concentrations above $272 \mu \mathrm{M}$ (Table 1). The length of the main shoot increased from 7.1 to $10.6 \mathrm{~cm}$ as media calcium concentration increased from 68 to $272 \mu \mathrm{M}$ (Table 1). There was no increase in shoot length as media calcium concentration was increased from 272 to 680 $\mu \mathrm{M}$. However, the greatest shoot length was recorded at the $3000 \mu \mathrm{m}$ medium calcium concentration. The number of nodes on the primary stem was statistically lower at a medium calcium level of $68.0 \mu \mathrm{M}$, but no consistent difference occurred at media calcium concentrations between 136 and $3000 \mu \mathrm{M}$ (Table 1).

Shoot tip viability increased and the number of axillary shoots arising from the primary stem decreased as the media calcium concentration increased from 68 to $340 \mu \mathrm{M}$ (Tables 1 and 2). Only $9.5 \%$ and $14.2 \%$ of the primary shoot tips were viable on medium with a calcium concentration of 68 and 136 $\mu \mathrm{M}$, respectively (Table 1), whereas shoot tip viability was $95.2 \%$ or more at root zone calcium concentrations of $476 \mu \mathrm{M}$ and higher. Axillary branching decreased dramatically as the medium calcium level increased (Tables 1 and 2). Plants cultured on $68 \mu \mathrm{M}$ calcium medium produced on average 3.8 axillary shoots. The axillary shoot number declined and was nearly zero at root zone calcium concentrations of $340 \mu \mathrm{M}$ or higher.

In general, the tissue calcium concentration increased as the medium calcium concentration increased (Table 2). At a medium calcium concentration of $340 \mu \mathrm{M}$ or higher, the tissue calcium concentration was statistically higher than the shoots grown on medium with a calcium concentration lower than 340 $\mu \mathrm{M}$ (Table 2). Interestingly, this medium calcium concentration coincided with the observation of near zero axillary shoots. The highest concentration of shoot calcium was observed when plants were cultured on $3000 \mu \mathrm{M}$ calcium medium (Table 2).

The roles of media calcium concentrations and the onset of shoot tip necrosis were studied developmentally by culturing 
A

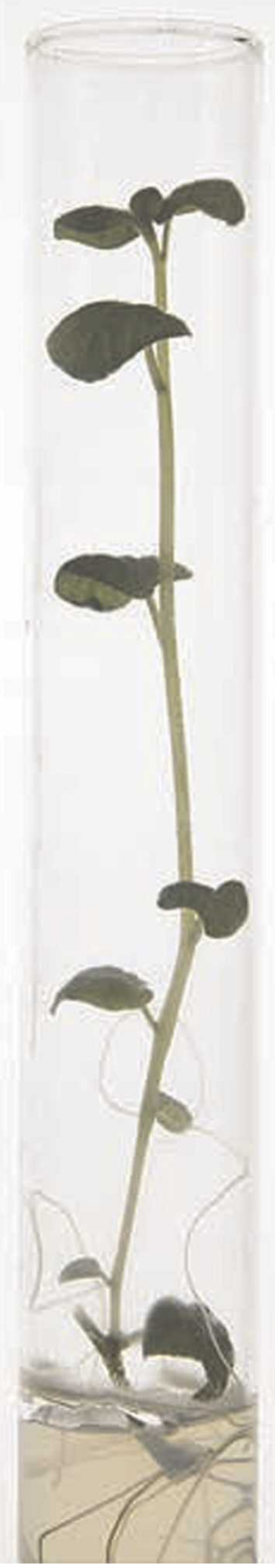

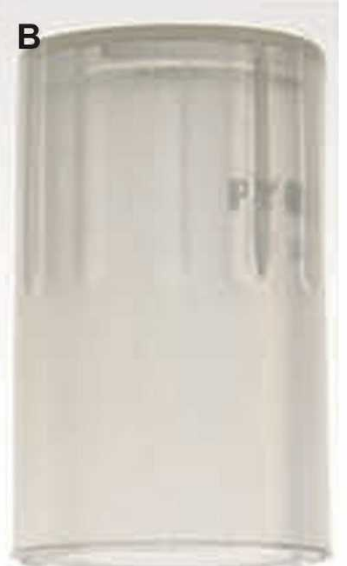

C

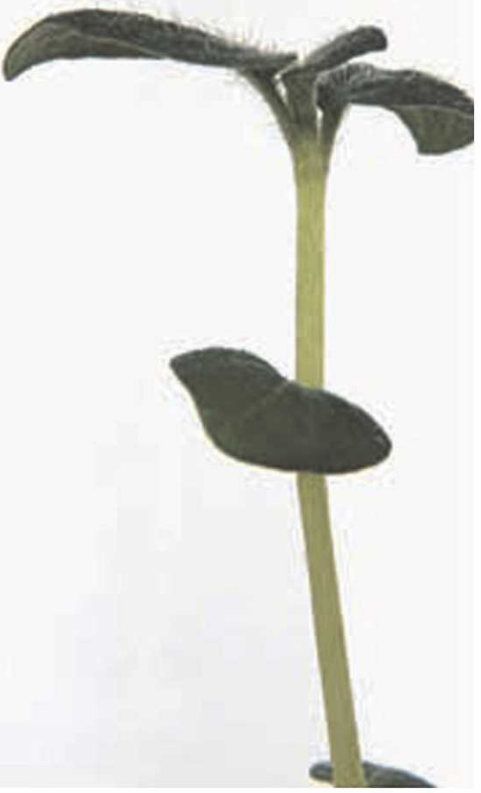

E

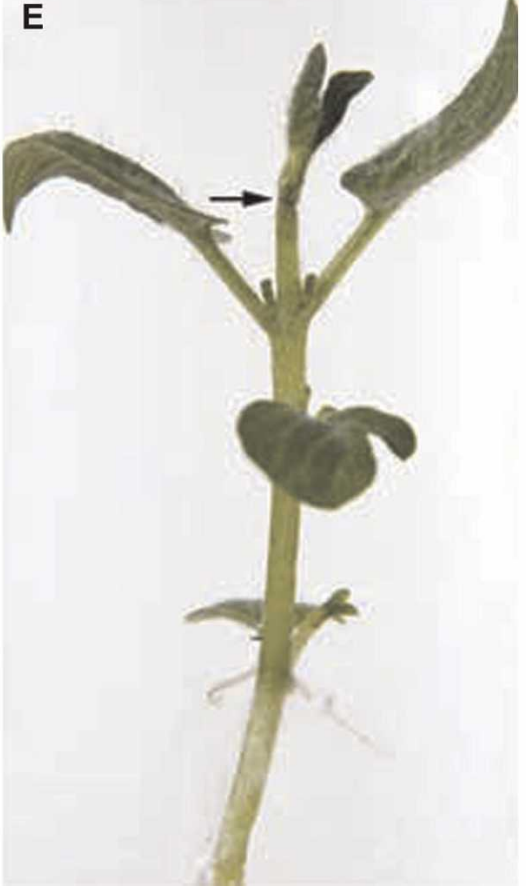

D
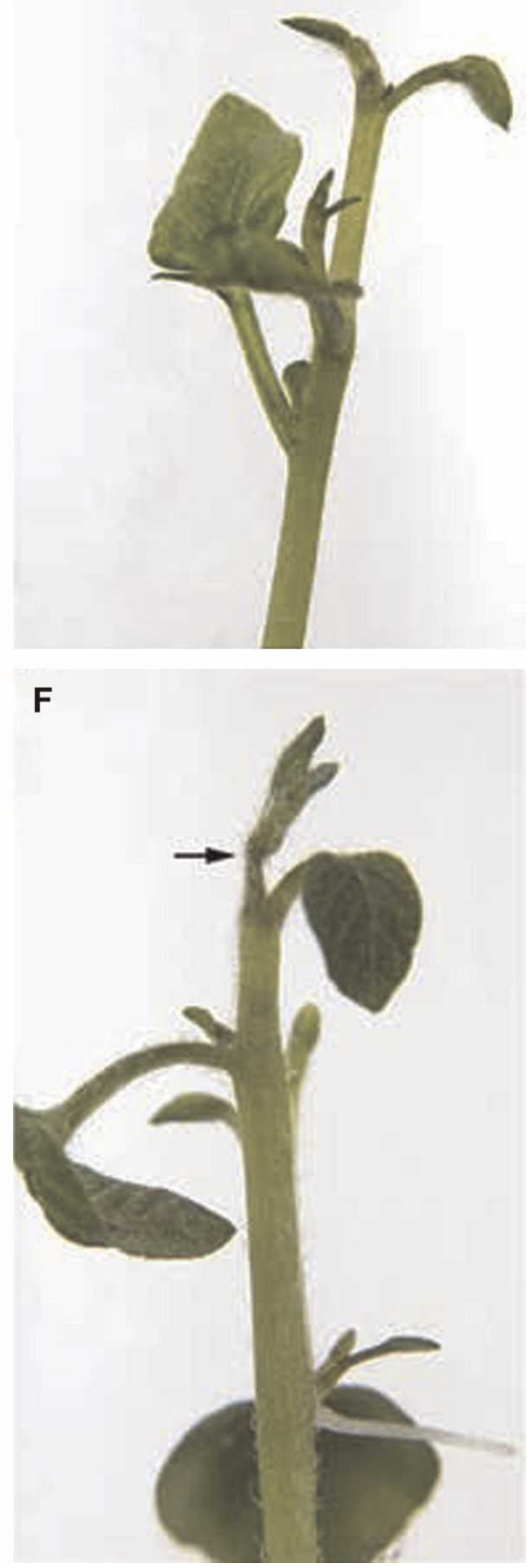

Fig. 1. 'Dark Red Norland' potato shoots cultured on sufficient (A and C) or suboptimal Ca medium (B and D-F). (A) Shoot cultured for $29 \mathrm{~d}$ on $3000 \mu \mathrm{M}$ Ca medium showing no shoot tip necrosis symptoms. (B) Shoot cultured for $29 \mathrm{~d}$ on $6.8 \mu \mathrm{M}$ Ca medium showing shoot tip necrosis symptoms. The death of the shoot apical meristem resulted in the loss of apical dominance and axillary branch development. (C) Apical portion of shoot cultured for $19 \mathrm{~d}$ on $3000 \mu \mathrm{M}$ Ca medium. (D-F) Progressive development of the symptom in shoots cultured for $19 \mathrm{~d}$ on $68 \mu \mathrm{M}$ Ca medium. (D) Reduced leaf expansion near the shoot apex. (E) Darkening of the stem 1 to $3 \mathrm{~mm}$ below the shoot tip (arrow). (F) Collapse of the darkened stem tissue in the subapical portion of shoot-tip (arrow). Note axillary branch development with the loss of apical dominance (B and D-F).

plants on sufficient $(1360 \mu \mathrm{M})$ and insufficient $(68 \mu \mathrm{M})$ calcium media concentrations and evaluating plants at four time intervals (Fig. 5, A-F). Shoot fresh weight increased over time (Fig. 5A). Plants cultured on $68 \mu \mathrm{M} \mathrm{Ca}$ medium showed a slower gain in fresh weight increase compared with plants cultured on $1360 \mu \mathrm{M}$ calcium medium (Fig. 5A). The mean fresh weight of plants cultured on $1360 \mu \mathrm{M}$ calcium was statistically greater than plants cultured on $68 \mu \mathrm{M} \mathrm{Ca}$ after $35 \mathrm{~d}$. Primary shoot length increased for plants on both calcium media concentrations until $21 \mathrm{~d}$ (Fig. 5B). Between 21 and $35 \mathrm{~d}$, plants cultured on $1360 \mu \mathrm{M}$ calcium medium steadily increased in length. In contrast, plants cultured on $68 \mu \mathrm{M}$ calcium medium 

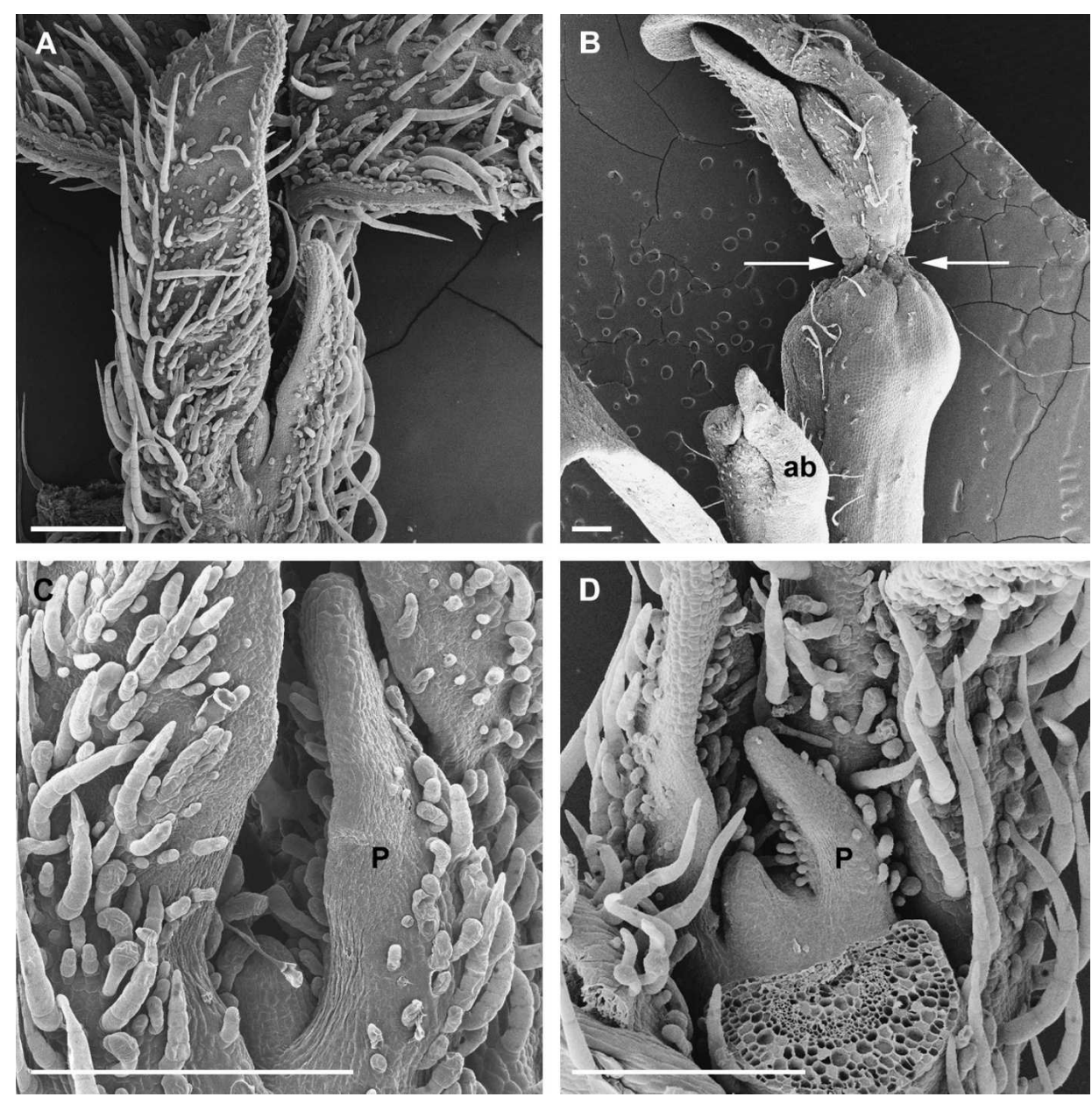

Fig. 2. Scanning electron micrographs of 'Dark Red Norland' potato shoot tips from plants cultured on $850 \mu \mathrm{M}$ Ca (A and C) or $6.8 \mu \mathrm{M} \mathrm{Ca} \mathrm{(B} \mathrm{and} \mathrm{D)} \mathrm{medium.} \mathrm{(A)} \mathrm{No} \mathrm{evidence} \mathrm{of} \mathrm{shoot} \mathrm{tip} \mathrm{necrosis} \mathrm{observed} \mathrm{after} 21 \mathrm{~d}$ of culture on $850 \mu \mathrm{M}$ Ca medium $($ bar $=50.0 \mu \mathrm{m})$. (B) Shoot tip necrosis is evident after $14 \mathrm{~d}$ of culture on $6.8 \mu \mathrm{M}$ Ca medium. Stem tissue is collapsed beneath the youngest leaf primordial (arrows). An axillary branch (ab) extends from the leaf axil $(\mathrm{bar}=50.0 \mu \mathrm{m})$. (C and D) Shoot apical meristems after $14 \mathrm{~d}$ on $850 \mu \mathrm{M} \mathrm{Ca}(\mathbf{C})$ or $21 \mathrm{~d}$ on $6.8 \mu \mathrm{M} \mathrm{Ca}(\mathbf{D})$ medium appear normal. Leaf primordia $(\mathrm{P})$ are found on the flank of the apical dome $(\mathrm{bar}=50.0 \mu \mathrm{m})$.
Plants cultured on $1360 \mu \mathrm{M}$ calcium medium showed a steady increase in the total amount of calcium per shoot from 14 through $35 \mathrm{~d}$ (Fig. 5F). In contrast, plants cultured on $68 \mu \mathrm{M}$ calcium medium showed little fluctuation in the total amount of shoot calcium over the course of the experiment. There were no visible differences in the number or morphology of roots on plants grown on the two media calcium concentrations. In both cases, five roots from each cutting extending to the bottom of the culture tube were generally observed after $14 \mathrm{~d}$. After $35 \mathrm{~d}$, plants on both calcium concentrations typically had eight roots from the original explant extending to the bottom of the culture tube.

Distribution of CALCIUM ALONG SHOOT LENGTH. The distribution of calcium along the length of the shoot was determined using shoots from plants grown on medium containing $1360 \mu \mathrm{M}$ calcium supplemented with ${ }^{45} \mathrm{Ca}$. Each shoot was divided into three equal lengths and radioactivity for each segment was determined (Fig. 6A). At $28 \mathrm{~d}$ after culture, the greatest concentration of radioactivity was observed in segments from the bottom portion of the shoot and the lowest concentration was in segments from the top of the shoot. The top portion of the shoot had lower radioactivity concentration compared with the middle or bottom segments (Fig. 6A).

The influence of shoot age on exhibited a much slower growth of primary shoot between 21 and $35 \mathrm{~d}$ (Fig. 5B). After $35 \mathrm{~d}$, plants on $68 \mu \mathrm{M}$ calcium medium had statistically shorter primary shoot length than plants cultured on $1360 \mu \mathrm{M}$ calcium medium (Fig. 5B). The mean number of nodes produced by the primary shoot on both media was identical until $21 \mathrm{~d}$. The mean number of nodes on the primary shoot between 21 and $35 \mathrm{~d}$ increased from 6.5 to 9.0 and from 6.6 to 11.3 on the 68 and $1360 \mu \mathrm{M}$ calcium medium, respectively (Fig. 5C).

No evidence for shoot tip death was observed at either root zone calcium concentration at $14 \mathrm{~d}$; however, after $21 \mathrm{~d}$, shoot tip viability declined dramatically for plants on $68 \mu \mathrm{M}$ calcium medium (Fig. 5D). Less than $20 \%$ of shoot tips were alive at $28 \mathrm{~d}$ on $68 \mu \mathrm{M}$ medium calcium (Fig. 5D). However, no shoot tip death occurred, even at $35 \mathrm{~d}$, when plants were cultured on $1360 \mu \mathrm{M}$ root zone calcium concentration (Fig. 5D). Axillary shoots were noticed earlier and at higher numbers in plants cultured on $68 \mu \mathrm{M}$ Ca concentrations (Fig. 5E). In these plants, axillary shoots increased dramatically between 21 and $35 \mathrm{~d}$ of culture, whereas no axillary shoots developed on plants grown on $1360 \mu \mathrm{M} \mathrm{Ca}$ medium for the entire experiment period. uptake and accumulation of ${ }^{45} \mathrm{Ca}$ was studied by quantifying radioactivity in a time course experiment (Fig. 6B). The total amount of radioactivity accumulated in the shoot increased with time. The radioactivity per plant increased over 2 -fold between 14 and $22 \mathrm{~d}$. However, this increase was only about $20 \%$ between 22 and 28 d (Fig. 6B).

Experiments were also conducted using ${ }^{45} \mathrm{Ca}$ to determine the distribution of calcium along the length of the shoot using autoradiography (Fig. 7). Autoradiographs from 28-d-old plants cultured on $1360 \mu \mathrm{M}$ calcium medium along with ${ }^{45} \mathrm{Ca}$ in each culture tube show radioactivity was distributed in a gradient along the length of plant (Fig. 7, A and B). Shoots appeared to have less radioactivity signal in the shoot tip compared with the base of the shoot (Fig. 7, A and B).

\section{Discussion}

Primary injury is LOCAlized to EXPANDing PITH CELlS IN THE SHOOT TIP. Our study is a detailed systematic investigation demonstrating the link between root zone calcium and shoot tip necrosis in potato. In calcium-deficient medium, shoot tip 

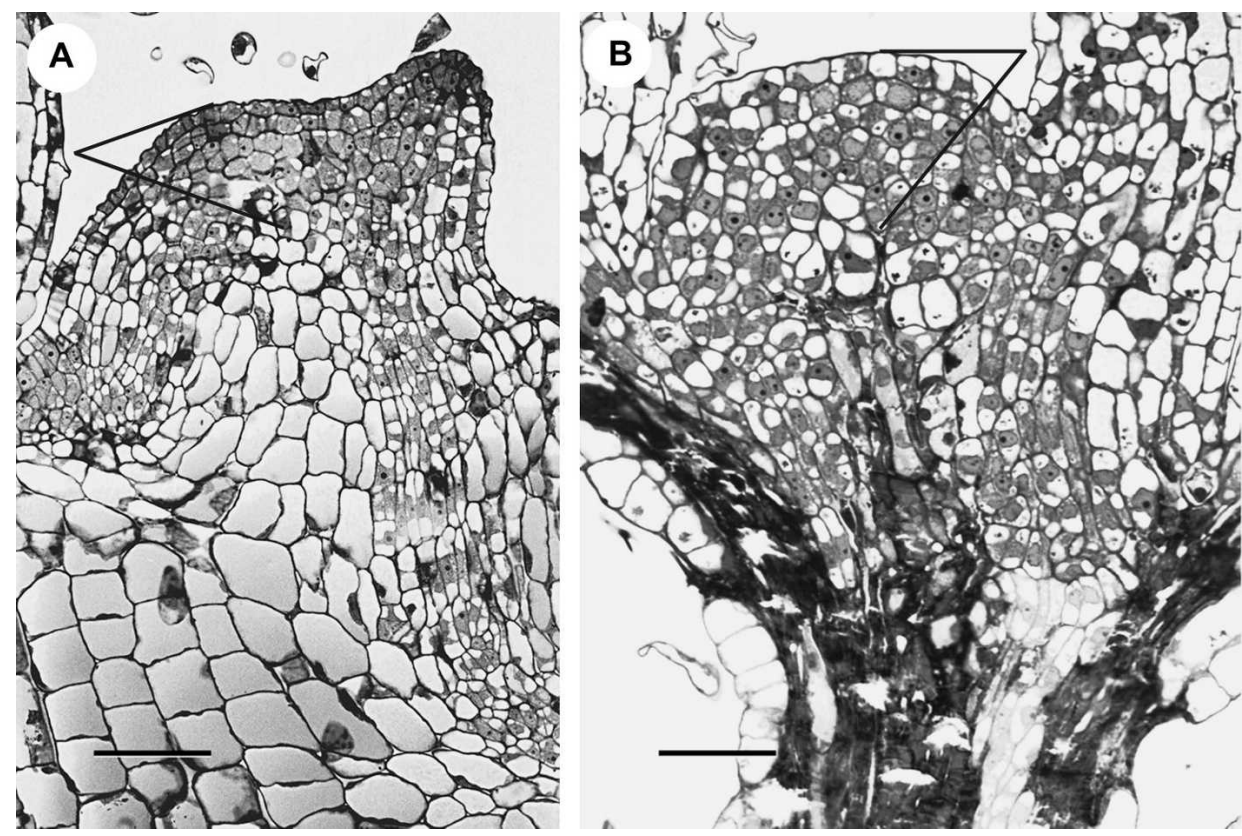

Fig. 3. Light micrographs of median longitudinal sections through shoot apical meristems from 'Dark Red Norland' potato shoots cultured for $21 \mathrm{~d}$ on $850 \mu \mathrm{M} \mathrm{Ca}(\mathbf{A})$ or $34 \mu_{\mathrm{M} \mathrm{Ca}}(\mathbf{B})$ medium. (A) Shoot apical meristem with tunicacorpus organization is indicated with lines. Leaf primordium on the flank of the shoot apical meristem. Ground tissue cells are expanded and vacuolated in the region of the stem beneath the shoot apical meristem responsible for internode elongation $(\mathrm{bar}=50.0 \mu \mathrm{m})$. (B) The shoot apical meristem (indicated with lines) of a plant cultured on 34 $\mu \mathrm{M}$ Ca medium is similar in appearance and organization to A. Ground tissue cells in the pith, cortex, and vascular tissue cells, as well as some epidermal cells, are not expanded and appear dark and necrotic $(\mathrm{bar}=50.0 \mu \mathrm{m})$.

1985) as well as reports from other shoot culture systems (Abousalim and Mantell, 1994). The experimental system used in our study afforded us a precise control of root zone calcium concentrations. Using this system, we defined a threshold concentration of $340 \mu \mathrm{M}$ calcium in the medium below which shoot tip necrosis develops, leading to a loss of apical dominance and the production of axillary shoots (Fig. 1, and Tables 1 and 2).

Ours is the first study investigating the structural basis for the development of shoot tip necrosis symptoms. Our results clearly demonstrate that the primary injury due to calcium deficiency was in the expanding pith cells below the shoot apex. While reduced leaf expansion near the shoot apex (Fig. 1) and browning below the shoot apex (Fig. 1, E and F) indicated that shoot tip necrosis was beginning, sectioned (Fig. 3) and cleared material (Fig. 4) revealed that the first necrotic cells were in

\section{A}

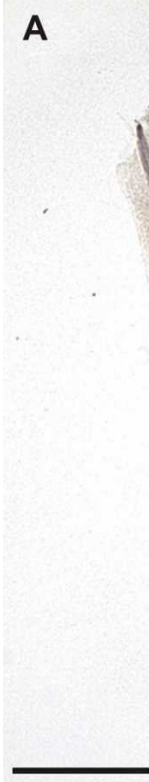

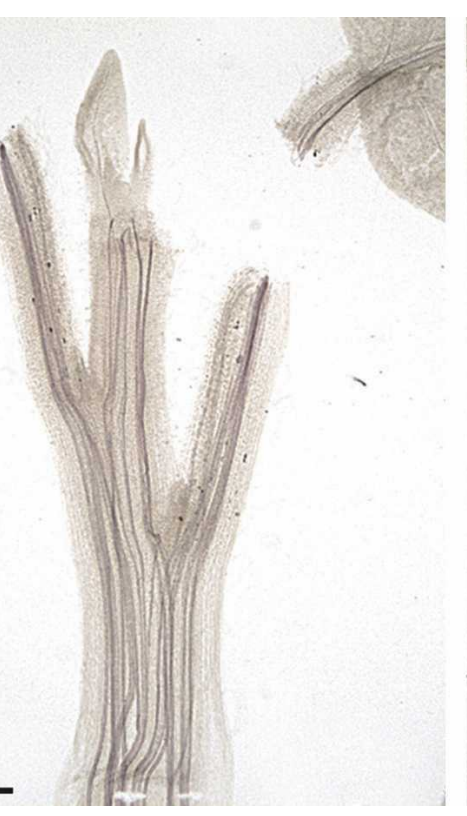
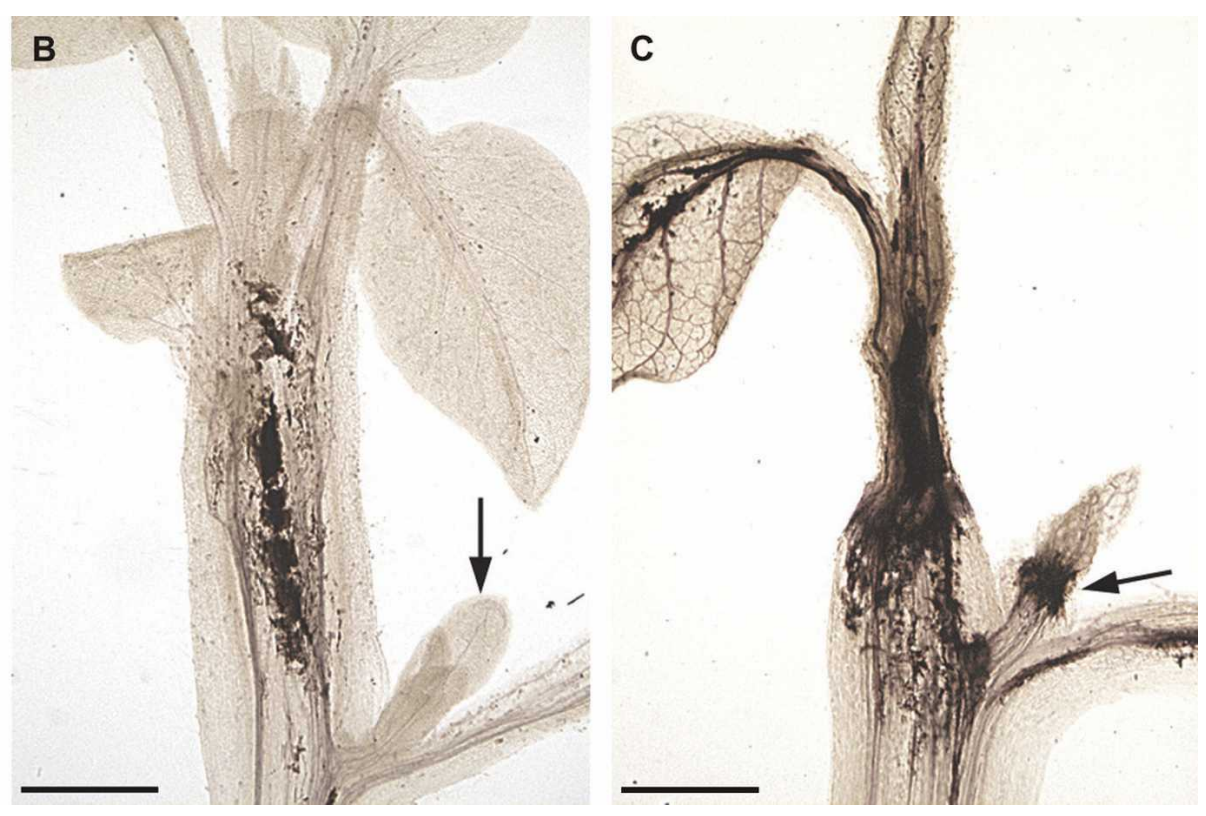

Fig. 4. Cleared 'Dark Red Norland' potato shoot tips stained with pararosaniline hydrochloride showing progression of shoot tip necrosis symptoms. (A) Shoot tip cultured for $25 \mathrm{~d}$ on $3000 \mu \mathrm{M}$ Ca medium. The vessels in the xylem tissue can be traced through the stem and into the developing leaves. No indication of cell breakdown in the shoot tip region (bar $=1.5 \mathrm{~mm}$ ). (B) Shoot tip cultured for $16 \mathrm{~d}$ on $6.8 \mu \mathrm{m}$ Ca medium. Necrosis occurs in the ground tissue comprising the pith two to four nodes below the shoot apical meristem, indicating that expanding cells in the pith are first to undergo senescence. Note the developing axillary shoot (arrow) (bar $=1 \mathrm{~mm}$ ). (C) Shoot tip cultured for $25 \mathrm{~d}$ on $34 \mu \mathrm{m}$ Ca medium showing advanced stages of shoot tip necrosis. The stem tissue is collapsed. Shoot tip necrosis symptoms are becoming visible on the developing axillary shoot (arrow) (bar $=1 \mathrm{~mm}$ ).

necrosis occurred after $14 \mathrm{~d}$ of culture, resulting in the development of axillary shoots (Figs. 1, B, D-F, and 6, and Table 1). These results are consistent with previous reports on potato shoot cultures (McCown and Sellmer, 1987; Sha et al., the region of the pith where cells were undergoing rapid cell enlargement. This enlargement was occurring within $3 \mathrm{~mm}$ of the shoot apex (Figs. 1-3) and it was in this portion of the shoot where the browning (Fig. 1, E and F) and collapse (Fig. 2B, 
Table 1. Influence of root zone calcium concentration on fresh weight, shoot length, number of nodes on primary stem, percentage of cultures with viable primary shoot tips, and number of axillary shoots arising from primary stem of 28-d-old 'Dark Red Norland' potato cultures. Shoots were cultured on MS media containing different $\mathrm{Ca}$ concentrations. Mean values followed by the same letter are not significantly different at $\alpha=0.05$ level. LSD values are as follows: fresh weight $/$ plant $=0.04 \mathrm{~g}$, shoot length $=1.2 \mathrm{~cm}$, number of nodes $/$ plant $=0.9$, and number of axillary shoots/plant $=0.7$.

\begin{tabular}{lclcccc}
\hline $\begin{array}{l}\text { Root } \\
\begin{array}{l}\text { Zne } \\
\mathrm{Ca}(\mu \mathrm{M})\end{array}\end{array}$ & $\begin{array}{c}\text { Replications } \\
(\text { no. })\end{array}$ & $\begin{array}{l}\text { Freshwt } \\
(\mathrm{g} / \mathrm{plant})\end{array}$ & $\begin{array}{c}\text { Shoot length } \\
(\mathrm{cm})\end{array}$ & $\begin{array}{c}\text { Nodes } \\
(\text { no./plant })\end{array}$ & $\begin{array}{c}\text { Viable } \\
\text { shoots } \\
(\%)\end{array}$ & $\begin{array}{c}\text { Axillary } \\
\text { shoots } \\
\text { (no./plant) }\end{array}$ \\
\hline 68.0 & 21 & $0.17 \mathrm{~d}$ & $7.1 \mathrm{f}$ & $7.1 \mathrm{~d}$ & 9.5 & $3.8 \mathrm{a}$ \\
136.0 & 21 & $0.19 \mathrm{bc}$ & $8.8 \mathrm{e}$ & $9.1 \mathrm{c}$ & 14.2 & $3.0 \mathrm{~b}$ \\
204.0 & 21 & $0.21 \mathrm{bcd}$ & $9.5 \mathrm{de}$ & $9.4 \mathrm{bc}$ & 57.1 & $1.7 \mathrm{c}$ \\
272.0 & 21 & $0.22 \mathrm{abc}$ & $10.6 \mathrm{~cd}$ & $10.1 \mathrm{ab}$ & 71.4 & $1.1 \mathrm{~cd}$ \\
340.0 & 20 & $0.21 \mathrm{bcd}$ & $10.2 \mathrm{~cd}$ & $10.1 \mathrm{ab}$ & 80.0 & $0.5 \mathrm{def}$ \\
408.0 & 21 & $0.21 \mathrm{bcd}$ & $9.5 \mathrm{de}$ & $9.4 \mathrm{bc}$ & 76.2 & $0.8 \mathrm{de}$ \\
476.0 & 21 & $0.22 \mathrm{abc}$ & $10.3 \mathrm{~cd}$ & $10.2 \mathrm{ab}$ & 95.2 & $0.1 \mathrm{ef}$ \\
544.0 & 21 & $0.21 \mathrm{bcd}$ & $10.4 \mathrm{~cd}$ & $10.3 \mathrm{a}$ & 100 & $0.0 \mathrm{f}$ \\
612.0 & 21 & $0.22 \mathrm{abc}$ & $10.9 \mathrm{bc}$ & $9.5 \mathrm{abc}$ & 100 & $0.0 \mathrm{f}$ \\
680.0 & 21 & $0.23 \mathrm{abc}$ & $10.4 \mathrm{~cd}$ & $9.9 \mathrm{abc}$ & 95.2 & $0.0 \mathrm{f}$ \\
1,360 & 21 & $0.25 \mathrm{a}$ & $11.8 \mathrm{ab}$ & $9.7 \mathrm{abc}$ & 100 & $0.0 \mathrm{f}$ \\
3,000 & 21 & $0.24 \mathrm{ab}$ & $12.3 \mathrm{a}$ & $9.6 \mathrm{abc}$ & 100 & $0.0 \mathrm{f}$ \\
\hline
\end{tabular}

Table 2. Influence of root zone calcium concentration on number of axillary shoots arising from primary stem of 26-d-old 'Dark Red Norland' potato cultures and whole shoot calcium concentration. Shoots were cultured on MS media containing different $\mathrm{Ca}$ concentrations. Mean values followed by the same letter are not significantly different at $\alpha=0.05$ level. LSD values are as follows: axillary shoots/plant $=1.1$, shoot $\mathrm{Ca}=18.92 \mathrm{mmol} \cdot \mathrm{kg}^{-1} \mathrm{DW}$, and entire plant $\mathrm{Ca}=3.4 \mu \mathrm{g} /$ plant.

\begin{tabular}{lcccc}
\hline $\begin{array}{l}\text { Root zone } \\
\mathrm{Ca}(\mu \mathrm{M})\end{array}$ & $\mathrm{N}$ & $\begin{array}{c}\text { Axillary shoots } \\
(\text { no./plant })\end{array}$ & $\begin{array}{c}\text { Shoot Ca } \\
\left(\mathrm{mmol} \cdot \mathrm{kg}^{-1} \mathrm{DW}\right)\end{array}$ & $\begin{array}{c}\text { Entire plant } \\
\mathrm{Ca}(\mu \mathrm{g} / \mathrm{plant})\end{array}$ \\
\hline 6.8 & 15 & $4.5 \mathrm{a}$ & $27.32 \mathrm{c}$ & $5.7 \mathrm{c}$ \\
68 & 15 & $5.5 \mathrm{a}$ & $18.25 \mathrm{c}$ & $5.5 \mathrm{c}$ \\
340 & 15 & $0.5 \mathrm{~b}$ & $48.87 \mathrm{~b}$ & $12.8 \mathrm{~b}$ \\
680 & 14 & $0.0 \mathrm{~b}$ & $47.55 \mathrm{~b}$ & $13.4 \mathrm{~b}$ \\
\hline
\end{tabular}

arrows) of tissue was observed. The shoot apical meristem tissue was not the first tissue to senesce; however, the shoot apical meristem ultimately senesced (Fig. 4). Our results clearly show that the death of the shoot apical meristem was a secondary injury that resulted in the loss of apical dominance and the formation of axillary branches (Fig. 1).

It is interesting to note that previous studies have termed this injury "shoot tip necrosis" although the necrosis per se occurs in the sub apical region of the shoot tip as our results demonstrate. This is probably because earlier studies primarily concentrated on the net result of calcium deficiency in a shoot culture system rather than investigating the location and the initiation of injury. Figure 3B demonstrates that the shoot apical meristem appears healthy in shoots (area indicated by lines), whereas injury has initiated in the subapical region. Based on our results, it may be more appropriate to term what has previously been called "shoot tip necrosis" as "subapical necrosis" associated with calcium deficiency in shoot culture systems.

Our study suggests that the primary injury results in a collapse of cells in the subapical region of the stem (Fig. 2B, arrows, and Fig. 3B). Death of the shoot apical meristem, as well as loss of apical dominance, are secondary injuries that follow the collapse of cells in the subapical region (Fig. 1, and Tables 1 and 2). How the collapse of cells in the subapical tissue systems results in the death of the apical meristem is an unresolved question. Perhaps the loss of vascular connection seen in clearings (Fig. 4, B and C) restricts water, photosynthates, and mineral nutrients to the shoot apex, which in turn would result in the death of the shoot apex. Furthermore, collapse of the cells in the subapical tissue system could stop the auxin transport to the shoot apex, resulting in a loss of apical dominance.

Association between root zone CALCIUM AND SUBAPICAL NECROSIS IN SHOOT CULTURES. Previous studies have provided evidence correlating root zone calcium and shoot apical necrosis in potato shoot cultures (McCown and Sellmer, 1987; Sha et al., 1985). Our study further explored this association by quantifying calcium in shoots in a time course study as well as by tracking ${ }^{45} \mathrm{Ca}$ supplied to the roots.

The onset for subapical necrosis symptoms and the calcium accumulation by the shoot in relation to medium calcium concentration was studied developmentally (Fig. 5, A-F). Up to $21 \mathrm{~d}$ of culture, the shoots developed on insufficient $(68 \mu \mathrm{M})$ and sufficient $(1360 \mu \mathrm{M})$ calcium media had very similar growth in terms of shoot fresh weight, shoot length, and number of nodes (Fig. 5). Furthermore, the shoots in both of the media showed no shoot tip necrosis. However, after $21 \mathrm{~d}$ of culture, the total $\mathrm{Ca}$ taken up by the shoot continued to increase in shoots grown on sufficient $\mathrm{Ca}$ (Fig. 5F). This increase in $\mathrm{Ca}$ in the shoot coincides with normal growth in the shoots grown on sufficient $\mathrm{Ca}$ (Fig. 5, A-C). Whereas the shoots on insufficient Ca media continue to grow and expand normally between 14 and $21 \mathrm{~d}$, these shoots did not take up additional $\mathrm{Ca}$ from the medium during this period (Fig. 5, B and F). The visual symptoms of browning in the subapical region appear between 21 and $28 \mathrm{~d}$ (Fig. 5D). These observations suggest that the health of the expanding cells below the apex was compromised during this time due to lack of $\mathrm{Ca}$ transport to the shoot, resulting in a dramatic reduction in tip viability. However, after $21 \mathrm{~d}$ of culture on insufficient calcium medium, subapical necrosis symptoms impact primary shoot length, the number of nodes on the primary shoot, the viability of the primary shoot tip, and the number of axillary shoots (Fig. 5, B-E). Interestingly, the rate of calcium accumulation by shoots cultured on sufficient calcium medium increases in a linear fashion over the entire culture period; however, on the insufficient calcium medium, the accumulation of calcium by the shoot did not change between 14 and $35 \mathrm{~d}$ of culture. This lack of further calcium transport into the shoots cultured on insufficient $\mathrm{Ca}$ coincides with the onset of subapical necrosis symptoms (Fig. 5).

The upper third of the shoot consistently had the least amount of calcium while the most ${ }^{45} \mathrm{Ca}$ signal was detected in the lower third of the shoot (Fig. 6). Calcium appears to be distributed in a gradient along the length of the shoot (Figs. 6B 

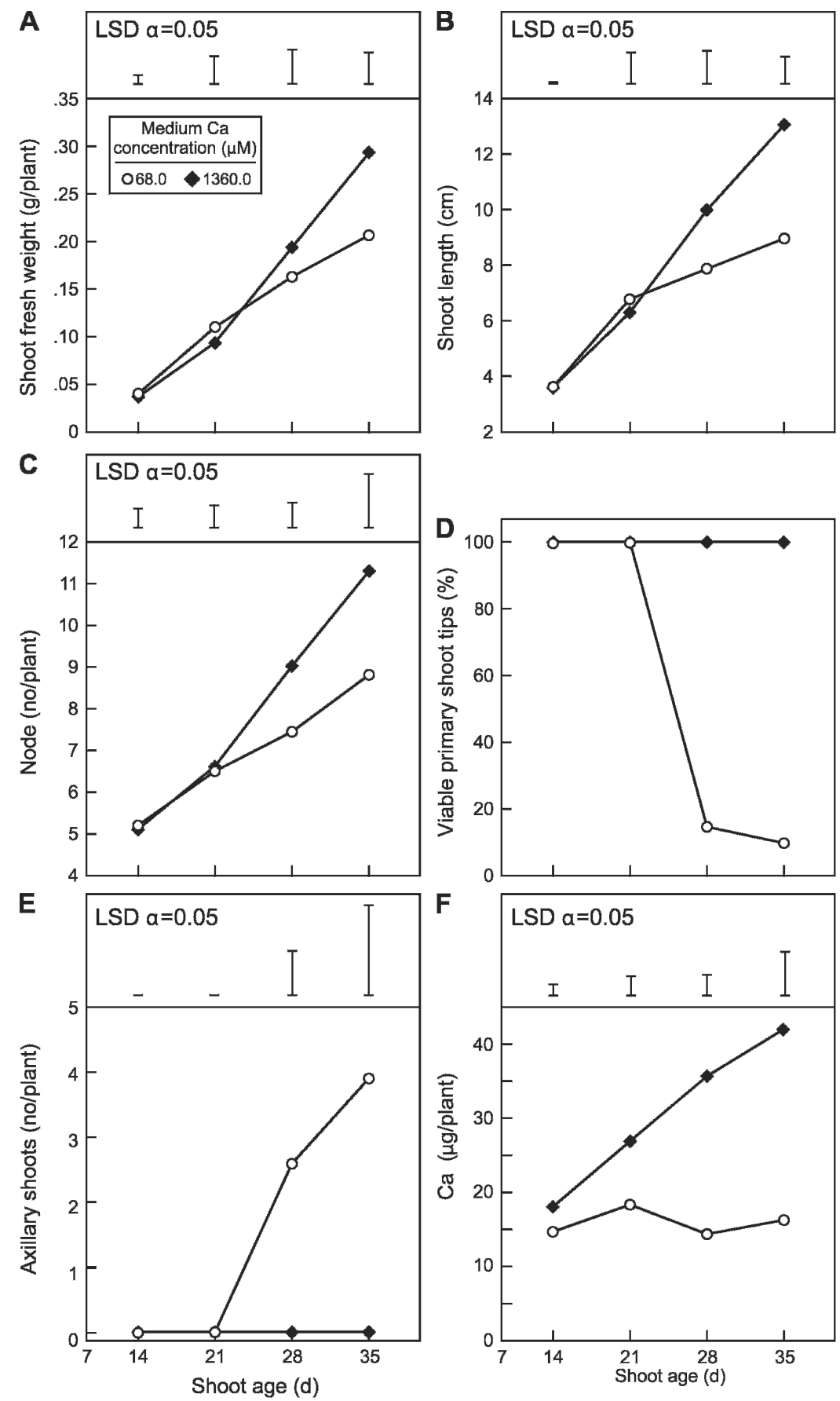

Fig. 5. Developmental changes in the growth, tip viability, and calcium accumulation in 'Dark Red Norland' potato shoots cultured on 68.0 or $1360 \mu \mathrm{M}$ Ca medium. Shoots were cultured in vitro for $14,21,28$, or $35 \mathrm{~d}$. (A) Shoot fresh weight. (B) Primary shoot length (axillary shoot length not measured). (C) Number of nodes on the primary shoot. (D) Percentage of viable primary shoot tips. (E) Number of axillary shoots arising from the primary shoot. (F) Calcium content per plant. At each sampling time, treatment means are statistically different at $\alpha=0.05$ level if separated by more than one bar length. Each treatment mean was determined using 20 samples except for calcium quantification, where 10 samples (two shoots combined per sample) were used.

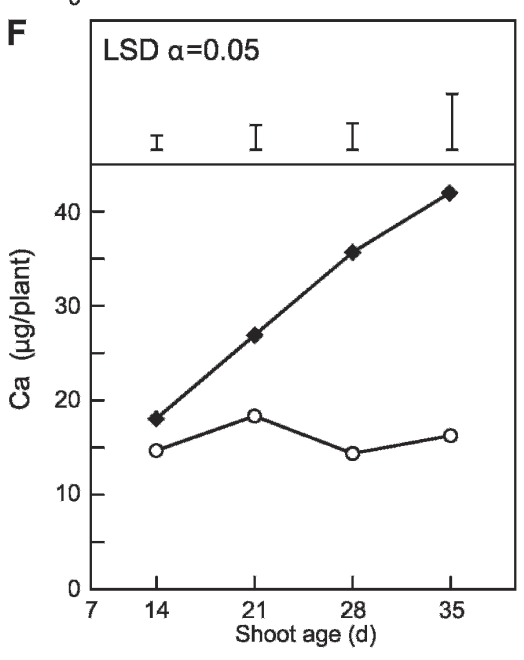

media) likely results in calcium deficiency in the expanding cells below the apex, leading to the subapical necrosis observed in our study. It is important to point out that the data presented in Fig. 5 are from destructive harvests at each sampling time. Thus, at each sampling time, different plants, albeit from the same treatment, were sampled.

CALCIUM TRANSPORT AND ROLE OF CALCIUM IN SHOOT DEVELOPMENT. The supply of calcium to the shoot tip depends upon many factors. Abdulnour et al. (1998) studied the calcium medium cation ratio on the uptake and distribution in micropropagated potato plants. Increasing the relative amount of calcium in the medium resulted in an increase in shoot calcium content (Abdulnour et al., 1998). The present study (Table 2) also shows that more calcium enters the shoot when more calcium is present in the medium. The efficiency with which plant roots take calcium ions from the medium, as well as transport of calcium within the shoot, influences the amount of calcium transported to the shoot tip. Vieitez et al. (1989) found that the presence of healthy roots seemed to prevent shoot tip necrosis during in vitro culture of Castanea sativa Mill. and Quercus robur L. White (2001) presented evidence for an apoplastic transport pathway of calcium across the root to the xylem, which in turn serves as a long-distance transport pathway.

Long-distance calcium transport is believed to occur via mass flow through the xylem. The high humidity within culture vessels depresses transpiration, ultimately reducing the transport of water and calcium to actively elongating portions of the stem. A slowing of transpiration occurs because of the buildup of nearly $100 \%$ relative humidity. Under these conditions, actively growing shoots can suffer from $\mathrm{Ca}$ deficiency because of lack and 7A). This means that shoot tips generally have much lower concentrations of Ca compared with the bottom (older) portions of the shoot. Furthermore, as discussed above, no additional calcium is transported to the shoot after $21 \mathrm{~d}$ of culture for shoots grown on insufficient Ca (Fig. 5F). Thus, the lower calcium concentration in the shoot tip combined with lack of additional calcium uptake in these shoots (on insufficient of water and $\mathrm{Ca}$ transport to the shoot tip (McCown and Sellmer, 1987). Restricted transpiration under a high humidity condition is also believed to result in localized calcium deficiency in lettuce (Lactuca sativa L.) (Collier and Huntington, 1983). Subapical necrosis results when a sufficient concentration of calcium is not supplied to the shoot tip. Since calcium is not mobilized from older tissues and redistributed 

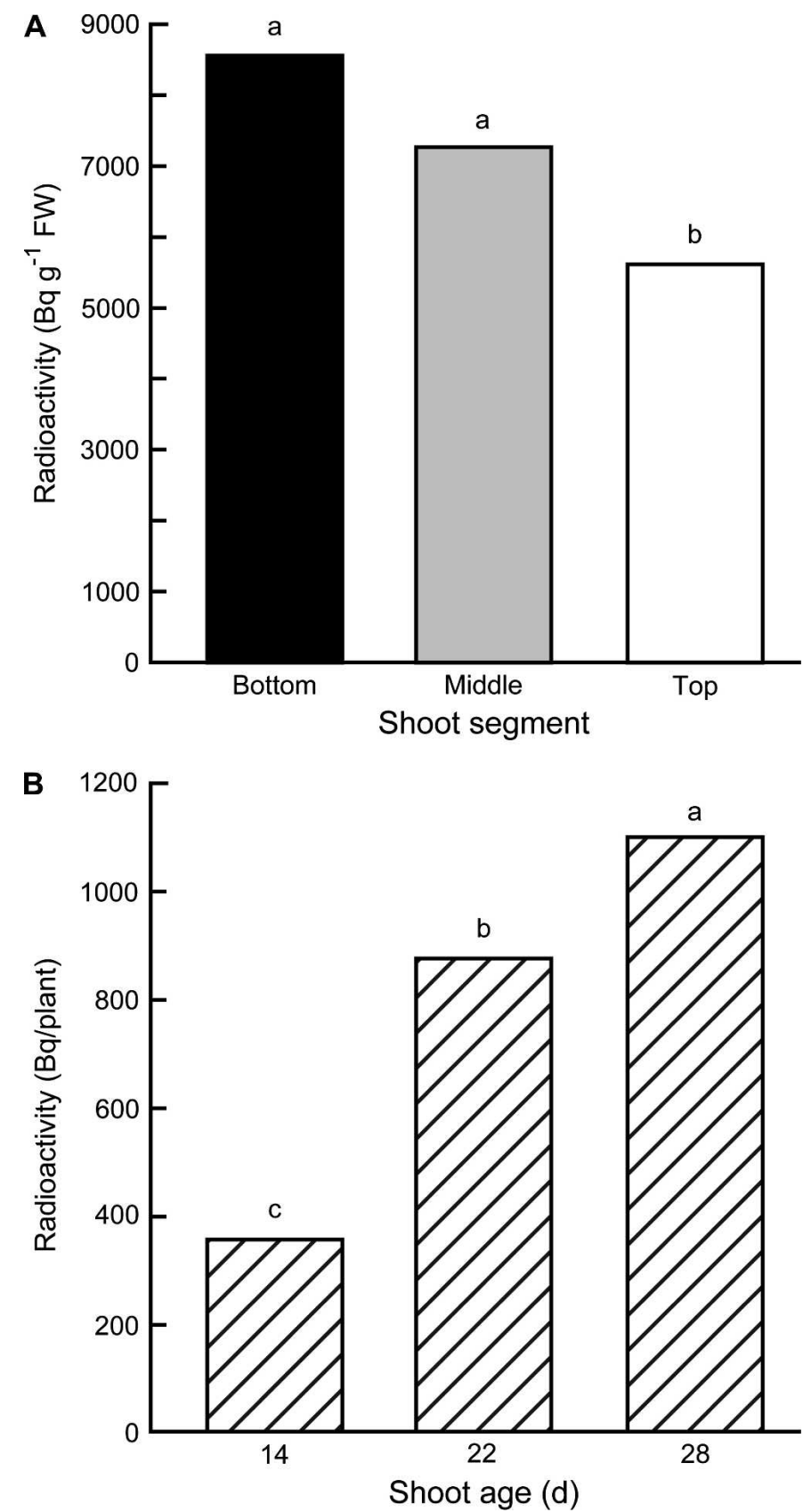

Fig. 6. Distribution of ${ }^{45} \mathrm{Ca}$ along the length of in vitro-cultured 'Dark Red Norland' potato shoots (A) and total radioactivity taken up by the plant at 14 , 22, and $28 \mathrm{~d}$ (B). (A) Nine single-node cuttings were cultured for $28 \mathrm{~d}$ in tubes on $1360 \mu \mathrm{M}$ Ca medium supplemented with $15.91 \mathrm{MBq}{ }^{45} \mathrm{Ca}$. Each shoot was divided into three equal-length segments and was weighed before being assayed for radioactivity $\left(\mathrm{LSD}_{\alpha}=0.05=1393.8 \mathrm{~Bq} \mathrm{~g}^{-1} \mathrm{FW}\right)$. (B) Shoot cultures were prepared as described for A. The entire shoot from ten 14-d-old cultures, ten 22-d-old cultures, and nine 28-d-old cultures were assayed for radioactivity $\left(\mathrm{LSD}_{\alpha}=0.05=138.7 \mathrm{~Bq} / \mathrm{plant}\right)$.

via the phloem, developing shoot tips must rely on the transpiration stream to deliver calcium via the xylem (White and Broadley, 2003). For shoots grown on the insufficient $\mathrm{Ca}$ media, a diminished calcium transport to shoot tip after $21 \mathrm{~d}$, the development of injury to expanding cells results.

What is the fundamental role calcium plays in maintaining viability of shoot tip?
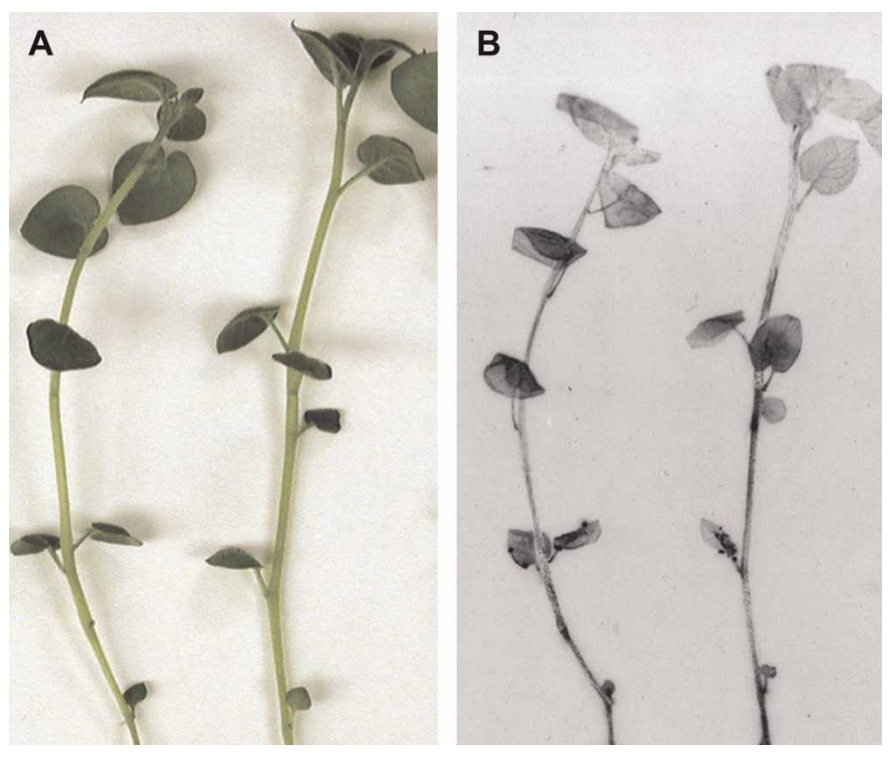

Fig. 7. Transport of ${ }^{45} \mathrm{Ca}$ into 'Dark Red Norland' potato shoots in vitro cultured on $1360 \mu \mathrm{M} \mathrm{Ca}$ medium with $15.91 \mathrm{MBq}{ }^{45} \mathrm{Ca}$ in each culture vessel. (A) Shoots from $1360 \mu \mathrm{M}$ Ca medium after $28 \mathrm{~d}$ of culture. (B) Autoradiograph of the same shoots in A.

The exact role for calcium at the shoot tip is not clearly defined. Membrane-associated calcium plays a role in cell plate assembly (Samuels and Staehlin, 1996; Wolniak et al., 1980). However, it does not seem that calcium deficiency leads to a general decline in vigor. Shoot fresh weight was nearly uniform except for the lowest medium calcium treatment. The production of axillary branches from the primary shoot apparently bolstered the entire shoot fresh weight. This suggests that low root zone calcium is not globally impacting growth, but it is influencing the health of expanding cells in the subapical region.

Calcium has a role in cross linking pectic acid fractions in the cell wall. Calcium is an essential constituent of the dimeric boron pectic polysaccharide rhamnogalacturonan II complex, and the removal of calcium from the complex with cyclohexanediomine tetracetic acid induces decay of the dimer (Matoh and Kobayashi, 1998). Thus, a localized calcium deficiency could compromise the health of the elongating cells below the shoot apex, leading to the death and collapse of the cells.

There is ample evidence indicating that calcium signals can modulate growth and development via calcium/calmodulinregulated protein kinases (Poovaiah, 1985). Evidence has been presented that cytoplasmic calcium concentration can regulate plant response to hormones such as auxin and gibberellins (Hepler and Wayne, 1985). because apical dominance is under hormonal control (Thimann and Skoog, 1934), it is possible that calcium is influencing apical dominance via a calcium/calmodulin type of system. Further studies using the system developed in the present investigation could help elucidate the mechanisms by which calcium regulates the growth and maintenance of apical dominance.

IMPLICATIONS FOR SEED POTATO SPROUT HEALTH. The progression of shoot tip necrosis symptoms that we observed in an in vitro system is very similar to that observed in sprouting tubers (Dyson and Digby, 1975). Dyson and Digby (1975) observed necrotic lesions within $5 \mathrm{~mm}$ of the shoot apex on shoots developing from 'Majestic' tubers. The necrotic lesions resulted in the death of the subapical tissue, death of the shoot 
apex, the loss of apical dominance, and the formation of lateral branching. Necrosis could be prevented by the treatment of the shoot tip with calcium salts (Dostal, 1943; Dyson and Digby, 1975). Dyson and Digby (1975) termed this condition subapical necrosis. As discussed above, subapical necrosis would be a more accurate term to describe the condition we studied than shoot tip necrosis because the primary site of injury from calcium deficiency is in the subapical portion of the stem. However, our results bear on potato sprout health. Our in vitro system would be a useful approach to elucidate the mechanism whereby calcium maintains sprout health.

Nutrient relations in potato have previously used in vitro systems (Abdulnour et al., 1998; Sha et al., 1985). The system we used allowed precise control of media calcium concentrations. Shoot tip necrosis during in vitro culture of 'Dark Red Norland' potato was shown to be a physiological disorder caused by a calcium deficiency. This in vitro culture system could prove very useful for studying calcium uptake and transport. Such studies may be very useful for understanding the fundamental role of calcium in sprout health.

\section{Literature Cited}

Abdulnour, J.E., D.J. Donnelly, and N.N. Barthakur. 1998. Cation and total macroelement concentration influence $\mathrm{Ca}$ uptake in micropropagated potato plantlets. Zeitschrift für Pflanzenernährun Düngung Bodenkunde 161:613-617.

Abousalim, A. and S.H. Mantell. 1994. A practical method for alleviating shoot-tip necrosis symptoms in in vitro shoot cultures of Pistacia cv. Mateur. J. Hort. Sci. 69:357-365.

Arora, R. and J.P. Palta. 1986. Protoplasmic swelling as a symptom of freezing injury in onion bulb cells. Plant Physiol. 82:625-629.

Boke, N.H. 1970. Clearing and staining plant materials with lactic acid and pararosanilinehydrochloride. Proc. Oklahoma Acad. Sci. 49: $1-2$.

Bush, D.S. 1995. Calcium regulation in plant cells and its role in signaling. Annu. Rev. Plant. Physiol. Plant Mol. Biol. 46:95-122.

Collier, G.F. and V.C. Huntington. 1983. The relationship between leaf growth, calcium accumulation and distribution, and tipburn development in field-grown butterhead lettuce. Scientia Hort. 21:123-128.

Dostal, R. 1943. Über die Nekrobiose der Kartoffeldunkelkeime. Phytopathologishe. Zeitschrift 14:484-496.

Dyson, P.W. and J. Digby. 1975. Effects on calcium on sprout growth and subapical necrosis in Majestic potatoes. Potato Res. 18:290-305.

Hanson, J.B. 1984. The functions of calcium in plant nutrition, p. 149208. In: P.B. Tinker and A. Läuchli (eds.). Advances in plant nutrition. Praeger, New York.

Hepler, P.K. and R.O. Wayne. 1985. Calcium and plant development. Annu. Rev. Plant Physiol. 36:397-439.
Hirschi, K.D. 2004. The calcium conundrum. Both versatile nutrient and specific signal. Plant Physiol. 136:2438-2442.

Kratzke, M.G. and J.P. Palta. 1986. Calcium accumulation in potato tubers: Role of the basal roots. HortScience 21(4):1022-1024.

Marry, M., K. Roberts, S.J. Jopson, I.M. Huxham, M.C. Jarvis, J. Corsar, E. Robertson, and M.C. McCann. 2006. Cell-cell adhesion in fresh sugar-beet root parenchyma requires both pectin esters and calcium cross-links. Physiol. Plant. 126:243-256.

Marschner, H. 1995. Mineral nutrition of higher plants. 2nd ed. Academic Press, London.

Matoh, T. and M. Kobayashi. 1998. Boron and calcium, essential inorganic constituents of pectic polysaccharides in higher plant cell walls. J. Plant Res. 111:179-190.

McCown, B.H. and J.C. Sellmer. 1987. General media and vessels suitable for woody plant culture, p 4-16. In: Cell and tissue culture in forestry. Martinus Nijhoff, Dordrecht, The Netherlands.

Murashige, T. and F. Skoog. 1962. A revised medium for rapid growth and bioassay with tobacco tissue cultures. Physiol. Plant. 15:473-497.

Ng, C.K.Y. and M.R. McAinsh. 2003. Encoding specificity in plant calcium signaling: Hot-spotting the ups and downs and waves. Ann. Bot. (Lond.) 92:477-485.

Palta, J.P. 1996. Role of calcium in plant responses to stresses: Linking basic research to the solutions of practical problems. HortScience 31(1):51-57.

Poovaiah, B.W. 1985. Role of calcium and calmodulin in plant growth and development. HortScience 20:347-352.

Samuels, A.L. and L.A. Staehlin. 1996. Caffeine inhibits cell plate formation by disrupting membrane reorganization just after the vesicle fusion step. Protoplasma 195:144-155.

Sanders, D., C. Brownlee, and J.F. Harper. 1999. Communicating with calcium. Plant Cell 11:691-706.

Sha, L., B.H. McCown, and L.A. Peterson. 1985. Occurrence and cause of shoot-tip necrosis in shoot cultures. J. Amer. Soc. Hort. Sci. 110(5):631-634.

Spurr, A.R. 1969. A low viscosity epoxy resin embedding medium for electron microscopy. J. Ultrastruct. Res. 26:31-43.

Thimann, K.V. and F. Skoog. 1934. On the inhibition of bud development and other functions of growth substances in Vicia faba. Proc. Royal Soc. Bot. 114:317-339.

Vieitez, A.M., C. Sanchez, and C. San-Jose. 1989. Prevention of shoottip necrosis in shoot cultures of chestnut and oak. Scientia Hort. 41:151-159.

White, P.J. 2001. The pathways of calcium movement to the xylem. J. Expt. Bot. 52:891-899.

White, P.J. and M.R. Broadley. 2003. Calcium in plants. Ann. Bot. (Lond.) 92:487-511.

Williams, R.R. 1993. Mineral nutrition in vitro: A mechanistic approach. Aust. J. Bot. 41:237-251.

Wolniak, S.M., P.K. Hepler, and W.T. Jackson. 1980. Detection of the membrane-calcium distribution during mitosis in Haemanthus endosperm with chlorotetracycline. J. Cell Biol. 87:23-32. 